Original Research Paper

\title{
Geophysical and Geological Studies of the Spread and Industrial Quality of Okurike Barite Deposit
}

\author{
${ }^{1}$ Anthony E. Akpan, ${ }^{1}$ Ebong D. Ebong, ${ }^{1}$ Stephen E. Ekwok and ${ }^{2}$ Sackey Joseph \\ ${ }^{1}$ Applied Geophysics Programme, University of Calabar, PMB 1115 Calabar Cross River State, Nigeria \\ ${ }^{2}$ Emery Geodata Services, Federal Housing Estate, Calabar Cross River State, Nigeria
}

\author{
Article history \\ Received: 04-05-2014 \\ Revised: 17-10-2014 \\ Accepted: 22-12-2014 \\ Corresponding Author: \\ Anthony E. Akpan \\ Applied Geophysics \\ Programme, University of \\ Calabar, PMB 1115 Calabar \\ Cross River State, Nigeria \\ E-mail: anthonyakpan@yahoo.com
}

\begin{abstract}
Investors have been avoiding the Okurike Barite due to paucity of information on its economic worth in spite of the high demand for barites by the local industries. This study was embarked upon to determine the spread and industrial quality of the barite deposit in order to bridge the information gap. The Okurike Barite mineralised site was investigated using geophysical Vertical Electrical Sounding (VES) and Electrical Resistivity Tomography (ERT) and geological techniques. The geophysical data were acquired along three profiles while the barite samples were analysed using the laboratory techniques in order to determine their elemental compositions and physical characteristics. Results show that the barites occur with gravels, breccias and weathered basement materials within a very limited region. The resistivity values of the barite mineralised region were observed to vary between 731 and $\sim 1500 \Omega \mathrm{m}$. The barites are characterised by specific gravity of 4.4 , density of $3.64 \mathrm{~g} / \mathrm{cm}^{3}$, porosity of $28 \%$, uniaxial compressive strength of $29.4 \mathrm{kN} / \mathrm{mm}^{2}$ and water absorption capacity of $1.5 \%$. The elements $\mathrm{Ba}$ and $\mathrm{Fe}$ dominate the elemental composition with 77.28 and $19.98 \%$ respectively. $\mathrm{BaO}, \mathrm{Fe}_{2} \mathrm{O}_{3}$ and $\mathrm{MnO}$ are preferentially enriched with abundance of $71.28,21.40$ and $6.10 \%$ respectively. These results show that the industrial quality of the Okurike Barite is high although its spread is limited.
\end{abstract}

Keywords: Barite Ore, Elemental Composition, Resistivity, Physical Parameters, Okurike-Nigeria

\section{Introduction}

In the Cretaceous Calabar Flank and the adjoining Pre-Cambrian Oban Massif, different economic minerals are deposited at many locations. Some of these economic mineral deposits, such as limestones, barites, ironstones and granites have been mapped using geological and geophysical techniques in order to assess their economic viability though on unequal scales (Akpan et al., 2011; 2014). Economic minerals whose worth have been established and are presently being mined at commercial scale include limestones and granites in Akamkpa Local Government Areas (LGAs) (Fig. 1A) (Akpeke et al., 2006; Akpan et al., 2011; 2014). However, commercial exploitation of these economic minerals in other locations e.g., Ikom and Biase, is yet to commence probably due to paucity of information on their economic viability. Economic viability and proximity to markets are the two major considerations that must be met before commercial exploitation of any mineral deposit. Barite is an economic mineral that is widely utilized in several industrial applications, operations and processes including weighting agents in the drilling industries, manufacturing of industrial wares e.g., safety glasses and radiation shields and as a source of barium chemicals in the chemical industries (Ene et al., 2012). The suitability of barite ores for industrial applications is basically due to their relatively high specific gravity of 4.5. Prior to the utilization of barites ores for their various industrial applications, the physical characteristics and chemical compositions of barite ores must compare favourably well with industrial quality standards for such minerals.

Barite mineralisation occurs extensively in both the Cretaceous and Pre-Cambrian geologic terrain of central and northern Cross River State in the form of vein-filling materials (Akpeke et al., 2006; Oden, 2012). These veins are of variable thicknesses that usually range from less than 1 to $\sim 2 \mathrm{~m}$ in some locations. Generally barite mineralisation in the Middle and Lower Benue Troughs in Nigeria is either associated with lead-zinc mineralization (Oladapo and Adeoye-Oladapo, 2011; Ene et al., 2012) (Fig. 2) or as a precipitate from hydrothermal solutions in the northern parts (Daspan and 
Imagne, 2010). In northern Cross River State, three major barite fields located at Aliforkpa, Gabu and Osina, have been identified and mapped (Ene et al., 2012). Other LGAs in Cross River State where barite mineralisation occurs include Ikom, Obubra, Etung and Biase (Akpeke et al., 2006; Oden, 2012) (Fig. 1A). Presently, there is no record of large-scale exploitation in any of these barites fields. Rather, small-scale miners throng these fields searching for barite veins to mine. This study is aimed at mapping and delineating the spatial distribution and characteristics of the Okurike Barite deposit in Biase, Nigeria using the electrical resistivity and geological techniques. The findings of this study are expected to bridge the existing information gap. The industrial properties of the barite ores will also be compared with industrial quality standards in order to assess their suitability for industrial uses.

\section{Site Description and Geology}

\section{Location, Physiography and Climate of the Study Area}

Okurike Community is located in Biase LGA in Cross River State, Nigeria (Fig 1A, B and 2). It lies between Longitudes 8.0543 and 8.9596 degrees $\mathrm{E}$ and Latitudes 5.6414 and 5.6437 degrees N. The study area lies in the southern parts of the Cross River Plain Province (CRPP) and belongs to the lowlands and scarplands of southeastern Nigeria (CRBDA, 1982; Petters, 1989). The area has a rugged and undulating topography with elevations varying between $50 \mathrm{~m}$ in the north-western and south-western regions and $120 \mathrm{~m}$ above mean sea level in the northeastern and south-eastern regions. A couple of sub-parallel stream channels that flow in a trellis drainage pattern drain the area. The NE-SW flowing Cross River is the major river that drains the area.

Okurike Community lies within the sub-equatorial south climatic region of West Africa. The annual rainfall in the area varies between 200 and $300 \mathrm{~mm}$ while ambient temperature fluctuates between $\sim 24^{\circ} \mathrm{C}$ in the rainy season and soars to $\sim 32^{\circ} \mathrm{C}$ in the dry season. Relative humidity hovers around $90 \%$ throughout the year. Two main climatic conditions, wet and dry seasons, are dominant in the area (Iloje, 2001). The wet season usually starts in April and ends in October with an annual break in August. Conventionally, the dry season usually begins in November and lasts until February. The two seasons are controlled by two dominant air masses that blow across the entire area. These are the Tropical Maritime air mass (SE Monsoon wind) that originates from the Atlantic Ocean and the southward blowing Tropical Continental air mass that blows across the Sahara Desert.

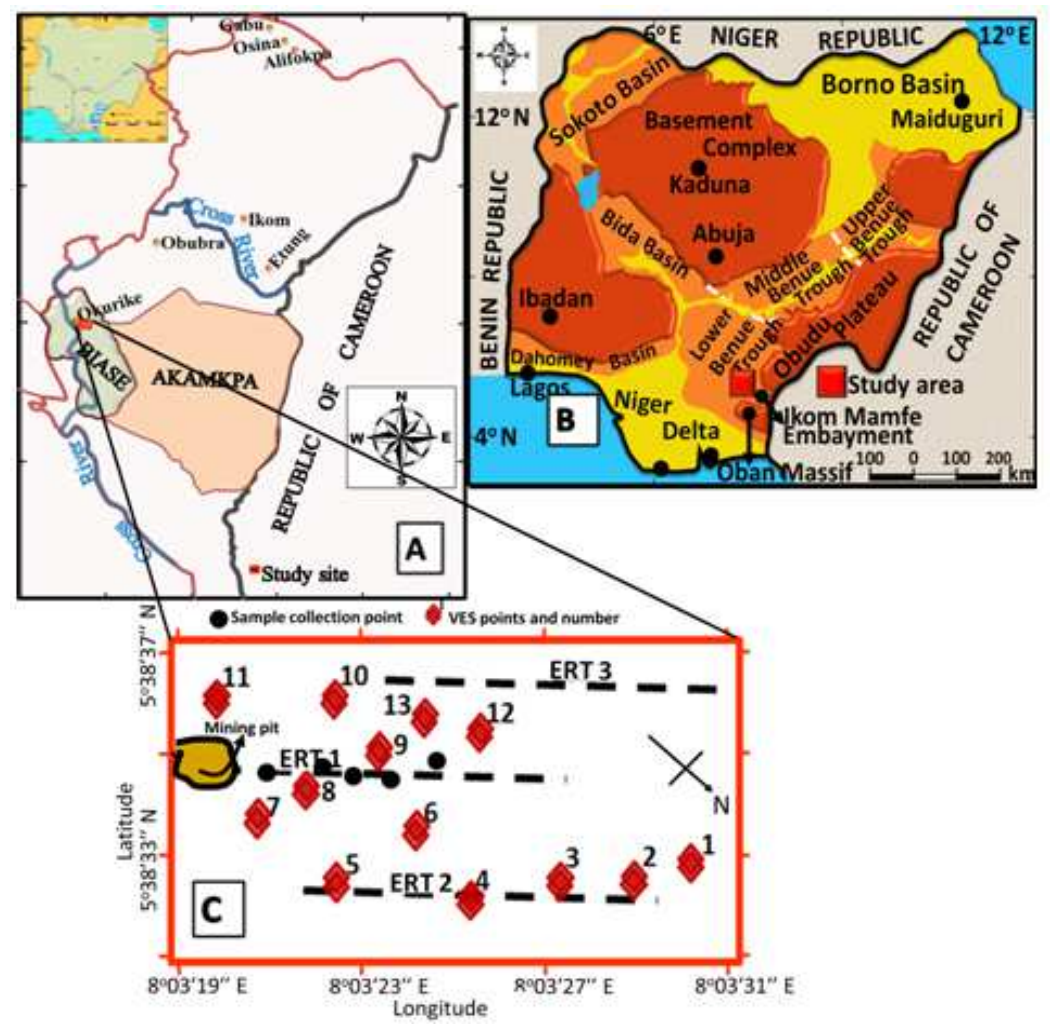

Fig. 1. Map of Cross River State showing the locations of Biase and Akamkpa LGAs and the study area (A), (B) generalized geological map of Nigeria (modified from Ekwueme et al., 1995) and (C) the distribution of VES stations and ERT profiles in the study site. Insert in (A): Map of Nigeria showing the location of Cross River State 


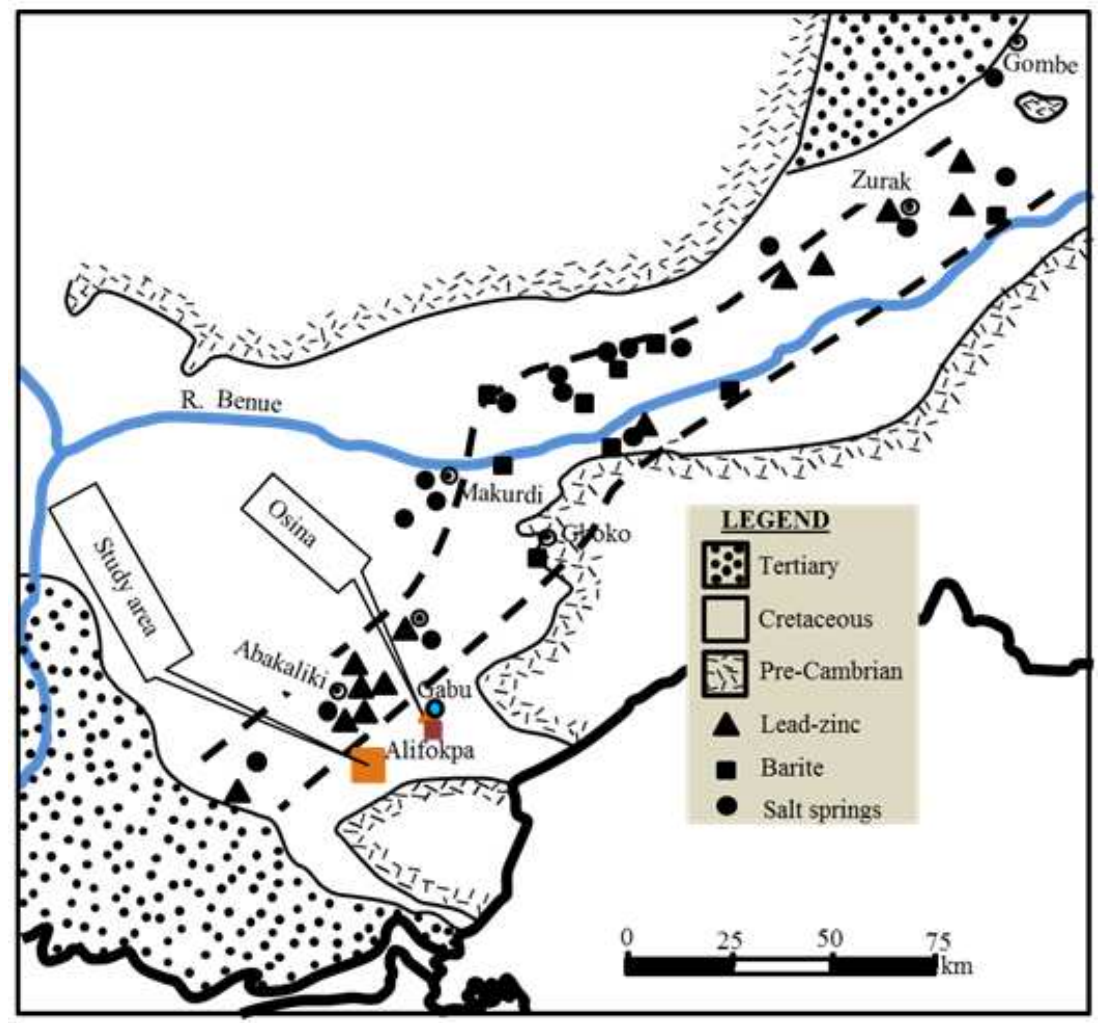

Fig. 2. Distribution of lead-zinc-barite and salt mineralisation along the Benue Trough, Nigeria (Modified from Cratchley and Jones, 1965)

\section{Geology and Stratigraphy}

The Okurike area falls within the Lower Benue Trough (Fig. 1C) and its sedimentation is equivalent to that of the Calabar Flank (CF), which Reyment (1965) called Odukpani Formation. The $\mathrm{CF}$ is one of the marginal basins in southern Nigeria. It consists of a series of sandstones, limestones and shales that rest unconformably on the basement complex. In the north, it is bounded by the Oban Massif while the Calabar Hinge Line that separates the basin from the Niger Delta Basin borders it in the south. The NE-SW trending Ikpe Platform also bound it in the west. In the east, the CF extends up to the Cameroun Volcanic Line. The CF consists of horsts e.g., Ituk High and grabens e.g., Ikang Trough, structures that are aligned in a predominantly NW-SE direction like other South Atlantic marginal basins (Reijers and Petters, 1987).

Sedimentation started in the CF with the deposition of fluvio-deltaic clastics and calcareous arkosic sandstones called Awi Formation in the Aptian time on the Precambrian Oban Massif (Adeleye and Fayose, 1978). The earliest marine transgression occurred in the Mid-Albian times with the deposition of the Mfamosing Limestone. This carbonate rock was deposited in a variety of depositional environments, which influenced their mineralogical compositions. The Mfamosing
Limestone is overlain by the Late Cenomanian-Turonian thick sequence of black to gray shale unit, the Ekenkpon Shale Formation (Ekwueme et al., 1995). The Ekenkpon Shale Formation is characterised by minor intercalation of marls and calcareous mudstones. A thick marl unit called the New Netim Marl Formation overlies the Ekenkpon Shales Formation.

The New Netim Marl Formation is unconformably overlain by the Late Campanian-Maastrichtian dark gray to bluish-black, friable to flaggy carbonaceous shales with bands of marly and silty to sandy shales and mudstones of the Nkporo Shale Formation (Reyment, 1965). The Nkporo Shales Formation sequence is overlain by a pebbly sandstone unit of the Tertiary Benin Formation.

\section{Methodology}

\section{Electrical Resistivity data Acquisition and Modelling}

Two field procedures of conducting electrical resistivity investigation (VES and ERT) were adopted to acquire the field data in the barite mineralized site and the adjoining areas. The SSR-MP-ATS model of a resistivity meter made by IGIS (India) that can measure earth resistances with an accuracy of $1 \mu \Omega$ was used in 
field data acquisition. Four stainless steel electrodes of $\sim 50 \mathrm{~cm}$ in length and $1.5 \mathrm{~cm}$ in diameter with one end tapered were used for transmitting electrical current into the ground and receiving the potentials generated by the passage of the transmitted current. At the investigated site, space limiting conditions such as topography and the heavily forested nature of the adjoining terrain constrained the maximum current electrode spacings (AB) to vary from $100 \mathrm{~m}$ to $400 \mathrm{~m}$. Corresponding receiving (potential) electrode spacings (MN) varied from $0.5 \mathrm{~m}$ at minimum current electrode spacing $(\mathrm{AB}=$ $2 \mathrm{~m}$ ) to $20 \mathrm{~m}$ at $\mathrm{AB}=400 \mathrm{~m}$. The Schlumberger electrode configuration was employed to acquire the VES data. The VES field procedure was executed by placing all the four electrodes collinearly with a common midpoint and gradually increasing the distance of the current electrodes from the centre after every successive reading. The spacing of the potential electrodes was only increased either when the apparent resistance reading was observed to be too low (Gowd, 2004) or an error message pops on the display prompting for the potential electrodes to be increased. The data recording sheets were designed to promote in-situ data quality checking. This was achieved by designing the data sheets in such a way that all new MNs values at the 'cross-over' points take on integer multiples of their previous MN values so that visual conversion and correlation of observed apparent resistances can be snappily done.

The measured field resistances were later transformed to apparent resistivity domain using Equation 1:

$$
r_{a}=p R\left[\frac{\left(\frac{\mathrm{AB}}{2}\right)^{2}-\left(\frac{\mathrm{MN}}{2}\right)^{2}}{\mathrm{MN}}\right]
$$

where $\mathrm{R}$ is the measured apparent resistance. The transformed apparent resistivity values were manually plotted against half-current spacing $(\mathrm{AB} / 2)$ on a bilogarithmic graph to generate curves. Where necessary, the curves were smoothened to remove the effects of lateral in homogeneities and other noisy signatures and thus enhance signal to noise ratio.

Conventional partial curve matching procedure, which was performed using auxiliary curves and charts, was adopted in the preliminary interpretation of the smoothened curves (Orellana and Mooney, 1966; Keller and Frischknecht, 1966). Initial layer parameters (thicknesses and resistivities) generated from the interpretation and the smoothened field data were used as the inputs into the inverse modelling phase. A VES data modelling code-RESIST, developed by Vender Velpen (1988) was used to model the data. Layer thicknesses observed on the walls of the locally mined pits were measured and used to constrain the thicknesses of each layer.
Using the RESIST code, a set of theoretical data was obtained from the initial layer parameters. The theoretical data were compared with the field data and the difference between the two was quantified using the Root Mean Square Error (RMSE) technique, which 5\% was set as the maximum acceptable value. At the beginning, the RMSE values in some cases were higher than the threshold value. These high RMSE values were eventually reduced to acceptable limits by performing a couple of iterations. At the end of the inverse modeling exercise, models that best fit the measured data in least squares sense using ridge regression were produced (Inman, 1975). Based on the results of the inversion, best fitting one Dimensional (1-D) resistivity models consisting of thicknesses and depths of the various geoelectric layers penetrated by the injected current were obtained. Figure $3 \mathrm{~A}, \mathrm{~B}$ and $\mathrm{C}$ show samples of the modeled VES curves observed and their 1-D equivalents.

The ERT data were acquired using SAS 1000 model of resistivity meter and the ES 10-64 switching unit from ABEM Instruments, Sweden. The ERT technique has the ability to image both lateral and vertical changes in electro-stratigraphy with a high accuracy (Caputo et al., 2003; Wilkinson et al., 2010). Three profiles were laid out at the Okurike Barite mineralization site. ERT 1 profile was aligned in tandem with a prominent NE-SW trending barite vein. ERTs 2 and 3 profiles were $50 \mathrm{~m}$ away on either side of ERT 1 but on the same direction as ERT 1. The arrangement of the VES stations and the ERT profiles are shown in Fig. 1C.

The lengths of ERTs 2 and 3 profiles were $172 \mathrm{~m}$ while ERT 1 was $150 \mathrm{~m}$ long. The Wenner electrode configuration that is reputed for having good vertical contact resolution (Zhou et al., 2002) was adopted. Minimum electrode separation was $4 \mathrm{~m}$ for ERTs 2 and 3 profiles and $3 \mathrm{~m}$ for ERT 1. The RES2DINV software (Loke, 2002) was used in performing the inversion of the apparent resistivity data. To produce a resistivity model, the software divides the subsurface into a number of blocks with fixed dimensions equal in number to the total number of data points. The smoothness-constrained least squares optimization technique was adopted to fit the synthetic model to the observed data (Loke and Barker, 1996). The RMS error technique was used in quantifying the extent of fit between the two sets of data. The subsurface models of each profile were stacked to form the pseudo 3-D model as shown in Fig. 4.

\section{Collection and Analyses of Barite Samples}

Five barite samples were collected from different locations within the barite mineralized area (Fig. IC). The elemental composition of the barite samples were analysed using the Atomic Absorption Spectrometer (AAS). 


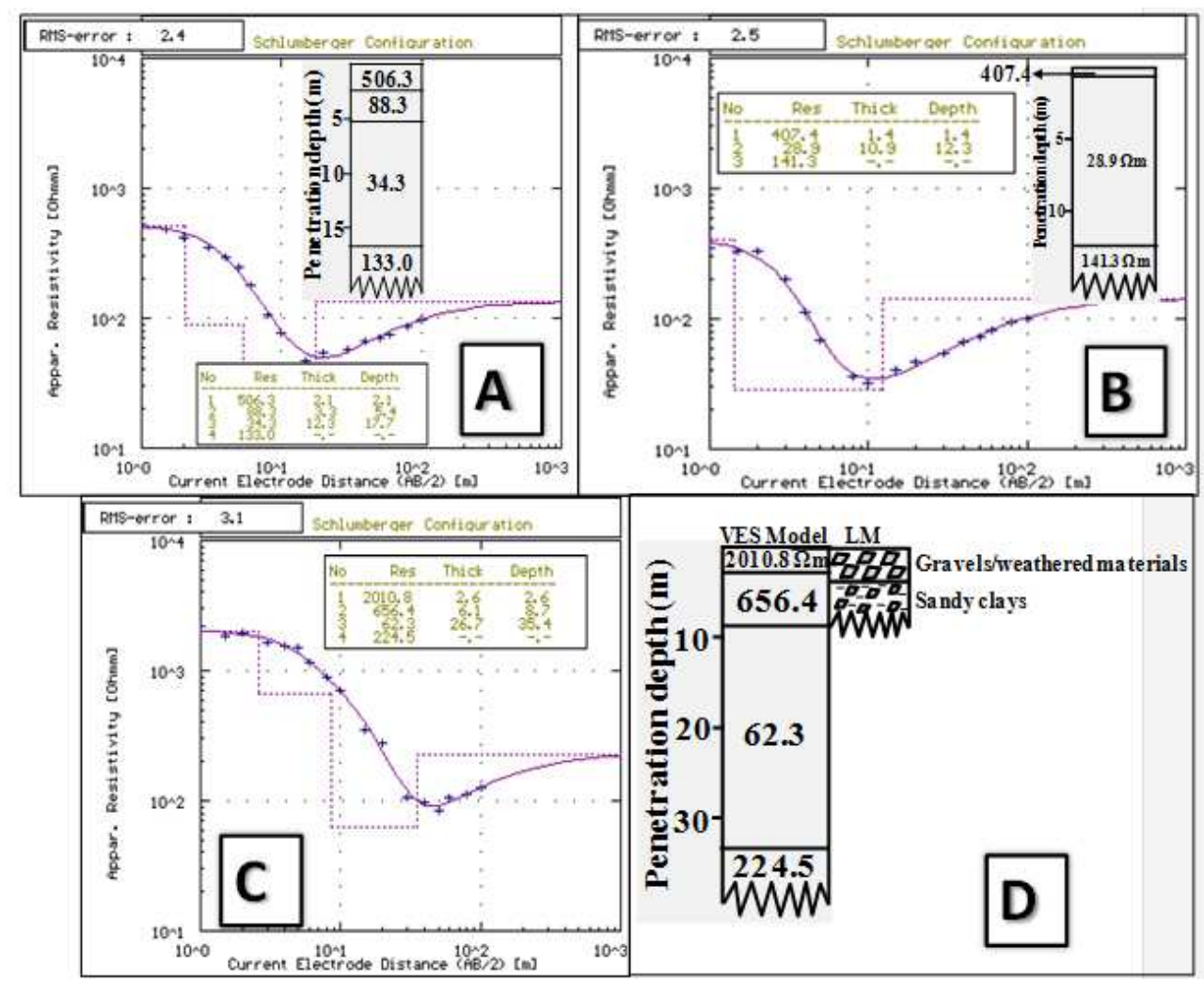

Fig. 3. Modelled VES curves observed at VES stations 1 (A), 5 (B) and 9 (C). Insert: correlation between 1-D resistivity model and Lithologic Model (LM)

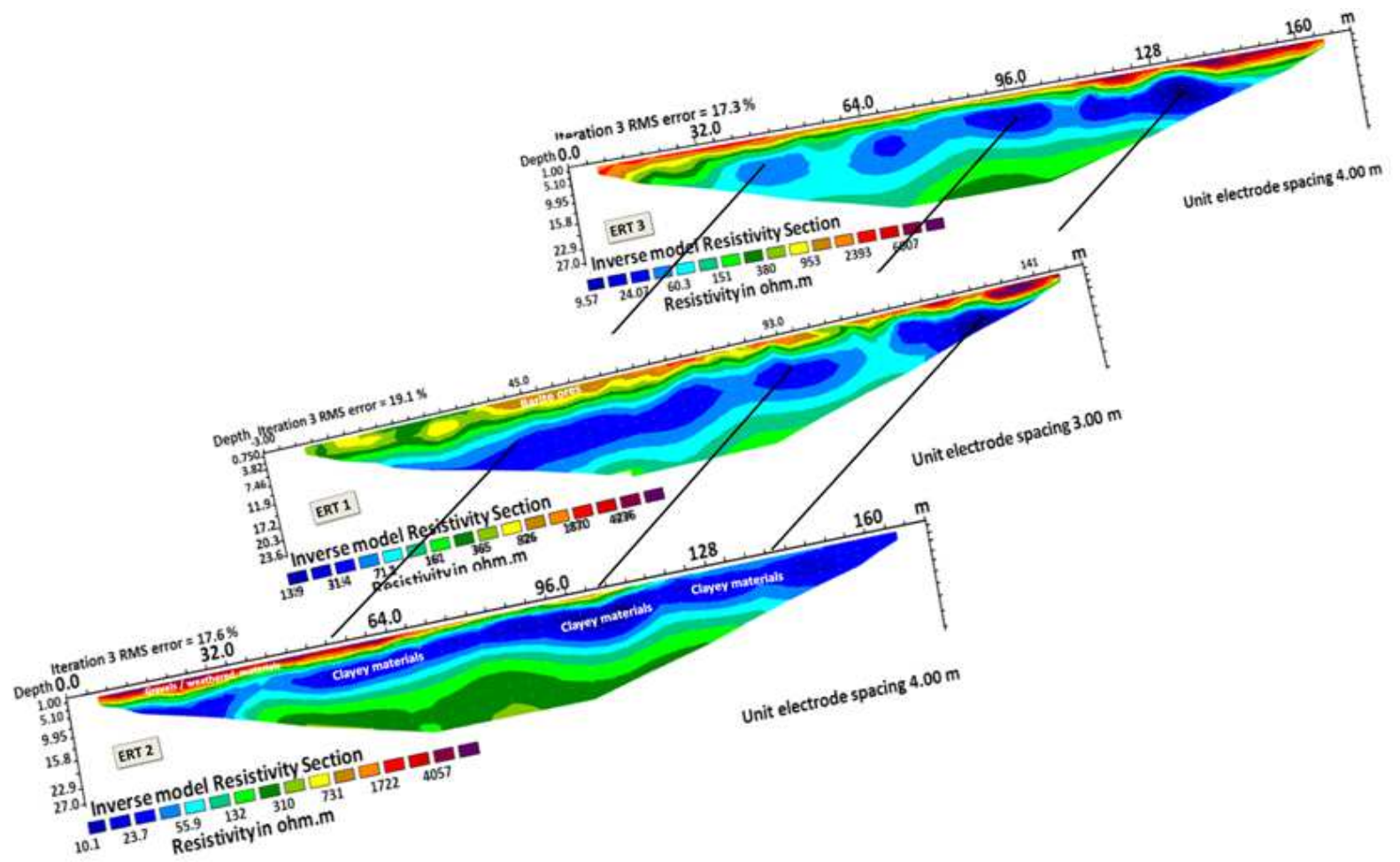

Fig. 4. Pseudo 3-D model of the study area generated by stacking 2-D images 
A pre-calibrated Inductively Coupled Plasma Mass Spectrometer (IC-PMS) was used in determining the major ore composition of the samples. References certified by the National Institute of Standards and Technology were used in calibrating the IC-PMS instrument. Specific gravity and porosity of the barite samples were determined using the pycnometric method in the laboratory. An unconfined compressive strength testing instrument manufactured by ELE International Ltd, UK was used in measuring the compressive strength of the samples.

\section{Results}

The results from the modelling of the VES data are summarized in Table 1. The results show that the shallow subsurface can be represented by a 3-4-layered structure with low to high resistivity values.
The results of the elemental composition of the Okurike Barites (Table 2) show that the barites are preferentially enriched in $\mathrm{Ba}(77.28 \%)$ and $\mathrm{Fe}$ (19.98\%). The composition of the other elements was observed to be generally less than $1 \%$. The results show that the ore contents of the Okurike Barite are dominated by $\mathrm{BaO}(71.28 \%), \mathrm{Fe}_{2} \mathrm{O}_{3}(21.40 \%)$ and $\mathrm{MnO}(6.10 \%)$. The total composition of other ores such as $\mathrm{SiO}_{2}, \mathrm{Al}_{2} \mathrm{O}_{3}, \mathrm{CaO}$ and $\mathrm{SrO}$ were less than $1.5 \%$. These results agree favourably well with the ore composition of other barite deposits in Cross River State and the (ASTM D-2938-79, 1980; Bieniawski and Bernede, 1979) standards (Table 3). Table 4 shows the physical properties of the Okurike Barites. The barites are characterised by mean specific gravity values of 4.4 , porosity of $28 \%$, Uniaxial Compressive Strength (UCS) of $29.4 \mathrm{kN} / \mathrm{mm}^{2}$, water absorption capacity of $1.5 \%$ and density of $3.64 \mathrm{~g} / \mathrm{cm}^{2}$.

Table 1. Summary of observed layer parameters inferred from the inverse modelling exercise

\begin{tabular}{|c|c|c|c|c|c|c|c|c|c|c|c|c|c|}
\hline \multirow[t]{2}{*}{$\begin{array}{l}\text { VES } \\
\text { station } \\
\text { no }\end{array}$} & \multirow[t]{2}{*}{$\begin{array}{l}\text { Approximate } \\
\text { number of } \\
\text { layers }\end{array}$} & \multirow[t]{2}{*}{$\begin{array}{l}\text { Modelling } \\
\text { RMS } \\
\text { error (\%) }\end{array}$} & \multicolumn{4}{|c|}{$\begin{array}{l}\text { Electrical resistivity of the } \\
\text { geoelectric layers }(\Omega \mathrm{m})\end{array}$} & \multicolumn{3}{|c|}{$\begin{array}{l}\text { Approximate } \\
\text { thickness of the } \\
\text { observed geoelectric } \\
\text { layers }(\mathrm{m})\end{array}$} & \multicolumn{3}{|c|}{$\begin{array}{l}\text { Approximate } \\
\text { depth to bottom } \\
\text { of the observed } \\
\text { geoelectric layers }(\mathrm{m})\end{array}$} & \multirow{2}{*}{$\begin{array}{l}\text { Estimated } \\
\text { thickness of } \\
\text { the barite }(\mathrm{m})\end{array}$} \\
\hline & & & $\rho_{1}$ & $\rho_{2}$ & $\rho_{3}$ & $\rho_{4}$ & $\mathrm{~h}_{1}$ & $\mathrm{~h}_{2}$ & $\mathrm{~h}_{3}$ & $t_{1}$ & $t_{2}$ & $\mathrm{t}_{3}$ & \\
\hline 1 & 4 & 2.4 & 506.3 & 88.3 & 34.3 & 133.0 & 2.1 & 3.3 & 12.3 & 2.1 & 5.4 & 17.7 & - \\
\hline 2 & 4 & 2.3 & 275.9 & 21.9 & 63.7 & 124.1 & 1.0 & 3.9 & 21.8 & 1.0 & 4.8 & 26.5 & - \\
\hline 3 & 4 & 3.9 & 813.1 & 34.6 & 53.1 & 742.7 & 1.4 & 4.8 & 26.2 & 1.4 & 6.2 & 32.4 & - \\
\hline 4 & 4 & 2.5 & 630.8 & 51.3 & 67.3 & 225.5 & 1.3 & 6.8 & 20.0 & 1.3 & 8.1 & 28.1 & - \\
\hline 5 & 3 & 2.5 & 407.4 & 28.9 & 141.3 & - & 1.4 & 10.9 & - & 1.4 & 12.3 & - & - \\
\hline 6 & 4 & 2.1 & 4822.8 & 1013.6 & 132.4 & 401.6 & 2.5 & 7.7 & 25.6 & 2.5 & 10.7 & 35.8 & 2.5 \\
\hline 7 & 4 & 3.3 & 967.8 & 24.5 & 21.5 & 489.9 & 1.7 & 7.0 & 5.5 & 1.7 & 8.7 & 14.2 & - \\
\hline 8 & 4 & 3.8 & 3254.2 & 1456.2 & 318.8 & 50.5 & 1.0 & 1.6 & 18.8 & 1.0 & 2.5 & 22.5 & 1 \\
\hline 9 & 4 & 3.1 & 2010.8 & 656.4 & 62.5 & 224.5 & 2.6 & 6.1 & 26.7 & 2.6 & 8.7 & 35.4 & 2.6 \\
\hline 10 & 4 & 5.8 & 5243.1 & 388.3 & 64.1 & 1671.1 & 3.0 & 9.1 & 30.8 & 3.0 & 12.2 & 43.0 & - \\
\hline 11 & 4 & 5.5 & 1133.4 & 211.7 & 44.8 & 196.8 & 1.8 & 1.0 & 16.6 & 1.8 & 2.4 & 19.0 & - \\
\hline 12 & 4 & 3.3 & 2241.3 & 214.7 & 33.8 & 750.3 & 1.0 & 3.3 & 11.5 & 1.0 & 4.3 & 15.8 & - \\
\hline 13 & 4 & 4.6 & 4544.2 & 485.0 & 124.8 & 82.8 & 2.1 & 7.4 & 23.0 & 2.1 & 9.5 & 32.4 & 2.1 \\
\hline Minimum & & & 275.9 & 21.9 & 21.5 & 50.5 & 1.0 & 1.0 & 5.5 & 1.0 & 2.4 & 14.2 & 1.0 \\
\hline Maximum & & & 5243.1 & 1456.2 & 318.8 & 1671.1 & 3.0 & 10.9 & 30.8 & 3.0 & 12.3 & 43.0 & 2.6 \\
\hline Range & & & 4967.2 & 1434.3 & 297.3 & 1620.6 & 2.0 & 9.9 & 25.3 & 2.0 & 9.9 & 28.8 & 1.6 \\
\hline Mean & & & 2065.5 & 359.6 & 89.4 & 424.4 & 1.8 & 5.6 & 19.9 & 1.8 & 7.4 & 26.9 & 2.1 \\
\hline $\begin{array}{l}\text { Standard } \\
\text { deviation }\end{array}$ & & 1811.4 & 446.1 & 79.0 & 460.2 & 0.7 & 2.9 & 7.4 & 0.7 & 3.4 & 9.2 & 0.7 & \\
\hline
\end{tabular}

Table 2. Mean major elemental composition of barite samples

\begin{tabular}{lll}
\hline Trace element & Composition in ppm & \% Composition \\
\hline $\mathrm{Ba}$ & 1976.7 & 77.28 \\
$\mathrm{Fe}$ & 511.1 & 19.98 \\
$\mathrm{Cr}$ & 8.0 & 0.31 \\
$\mathrm{Cd}$ & 0.9 & 0.03 \\
$\mathrm{~Pb}$ & 6.7 & 0.26 \\
$\mathrm{Cu}$ & 14.4 & 0.56 \\
$\mathrm{Ag}$ & 1.4 & 0.05 \\
$\mathrm{Ni}$ & 2.2 & 0.09 \\
$\mathrm{Mn}$ & 18.9 & 0.74 \\
$\mathrm{Hg}$ & 1.5 & 0.06 \\
$\mathrm{~V}$ & 16.0 & 0.63 \\
\hline
\end{tabular}


Table 3. Mean major oxides from the sample

\begin{tabular}{|c|c|c|c|c|c|c|c|}
\hline \multirow{2}{*}{$\begin{array}{l}\text { Sample } \\
\text { location }\end{array}$} & \multicolumn{6}{|c|}{$\%$ Composition of major oxides } & \multirow[b]{2}{*}{$\mathrm{SrO}$} \\
\hline & $\mathrm{BaO}$ & $\mathrm{Fe}_{2} \mathrm{O}_{3}$ & $\mathrm{SiO}_{2}$ & $\mathrm{MnO}$ & $\mathrm{Al}_{2} \mathrm{O}_{3}$ & $\mathrm{CaO}$ & \\
\hline Okurike* & 71.28 & 21.40 & 0.05 & 6.10 & 0.74 & 0.25 & 0.06 \\
\hline $\mathrm{Gabu}^{* *}$ & 64.60 & 18.31 & 1.58 & 14.00 & 0.59 & 0.28 & 0.14 \\
\hline Aliforkpa** & 55.33 & 22.32 & 1.39 & 17.25 & 2.57 & 0.03 & 0.64 \\
\hline Osina** & 58.77 & 25.65 & 1.47 & 10.43 & 2.41 & 0.29 & 0.63 \\
\hline
\end{tabular}

* Results from present study

**Mean values outside the study area (Ene et al., 2012)

Table 4. Mean physical properties of Okurike Barites

\begin{tabular}{lr}
\hline Physical property/unit & Measured value \\
\hline $\mathrm{UCS} *\left(\mathrm{kN} / \mathrm{mm}^{2}\right)$ & 29.40 \\
Density $\left(\mathrm{g} / \mathrm{cm}^{3}\right)$ & 3.64 \\
Porosity $(\%)$ & 28.00 \\
Water absorption capacity $(\%)$ & 1.50 \\
Specific gravity & 4.40 \\
\hline UCS*-Uniaxial Compressive Strength
\end{tabular}

UCS*-Uniaxial Compressive Strength

\section{Discussion of Results}

Materials that dominate the first geoelectric layer in the study area are characterised by resistivity values that vary from 275.9 to $5243.1 \Omega \mathrm{m}$ (mean of $2065.5 \Omega \mathrm{m}$ ). The thickness of this layer was estimated to vary from 1 to $3 \mathrm{~m}$ (average of $1.8 \mathrm{~m}$ ). The wide resistivity range $(>4960 \Omega \mathrm{m})$ is reflective of the heterogeneity in materials that cap the entire lithostratigraphic sequence. Where moderately resistive argillaceous materials such as clay, silt and lateritic materials were dominant, resistivity values were observed to be low $(<300 \Omega \mathrm{m})$. In locations where poorly sorted clastic materials such as breccias, gravels, arkosic sandstones and other weathered basement materials were exposed, resistivity was high $(>1000 \Omega m)$. The materials with high resistivity were dominant near the VES stations 6,8 and 13 since the area under investigation is within a sediment-basement contact. The gravelly and breccial materials were considered products of weathering and fragmentation of basement materials that are close to their provenance areas.

The second layer is characterised by relatively low resistivity $(<220 \Omega \mathrm{m})$ values except around the VES stations $6,8,9,10$ and 13 where comparatively high resistivity values resulting from the gradational sequence of the gravelly materials were observed. Argillaceous materials mixed with varying degrees of arenaceous materials as confirmed by the exposed part of the mining pit dominate this layer. Depths to the bottom of this layer were estimated to vary between 2.4 and $12.3 \mathrm{~m}$ (mean of $7.4 \mathrm{~m}$ ).

The materials in the third layer were speculated to be dominated by sandy-clay and fractured basement materials with characteristic resistivity values that range from 21.5 to $318.8 \Omega \mathrm{m}$ (mean resistivity of $89.4 \Omega \mathrm{m}$ ). Depth to the bottom of this layer is $\leq 43 \mathrm{~m}$. The materials in the fourth layer are characterised by comparatively high resistivities $\geq 400 \Omega \mathrm{m}$ except around the VES stations 1, 2, 4, 8, 9 and 13 where lower resistivities were observed. This layer was speculated to be dominated by weathered/fractured/fresh basement materials. Thicknesses of the materials in layer 4 could not be determined from the data acquired in the field.

The subsurface image from ERT 1 show that the area is overlain by thin $(<5 \mathrm{~m})$ materials. The resistivity of these materials varies from $\sim 300 \Omega \mathrm{m}$ at the areas dominated by sandy clay to $4,057 \Omega \mathrm{m}$ at areas dominated by clastic materials. The wide range in the observed resistivity values is once again indicative of the variability in the textural properties of this layer. The area where the barite vein is exposed lies between 40 - to $100-\mathrm{m}$ along the profile and is characterised by resistivity values that range from 731 to $\sim 1500 \Omega \mathrm{m}$. The thickness of the barite-enriched region of the profile is $\sim 4 \mathrm{~m}$. The wide range in resistivity values suggest that the barites occur along with more resistive clastic materials (Oden, 2012). Beyond $100 \mathrm{~m}$, the clastic materials with their characteristic high resistivities were exposed towards the end of the profile.

A layer dominated by clayey sand and sandy clay underlies the resistive top layer. These materials are nearly homogeneous with narrow resistivity range of 45 $\Omega \mathrm{m}$ (from $\sim 10$ to $55 \Omega \mathrm{m}$ and depth to bottom of $\sim 20 \mathrm{~m}$. These clayey materials are exposed in the mining pits and towards the end of ERT 2 profile. The third layer is a sand dominated layer with resistivity values higher than that of the second layer. The electrostratigraphic sequence observed in ERT 1 profile was also observed in ERTs 2 and 3 profiles (Fig. 4). At about $110 \mathrm{~m}$ along ERT 2, the thin gravelly overburden materials thin out leaving the underlying clayey materials on the surface.

The results show that barite enrichment in the area is limited in both lateral and vertical extents. Along ERTs 2 and 3 profiles, there is no evidence of barite mineralisation. The VES results also reveal that barite mineralized at the site is a localized feature with thickness less than $4 \mathrm{~m}$ and no reasonable lateral spread beyond ERT 1. Identifying the barite-enriched layer from the resistivity results outside the major vein was difficult. This problem is usually caused by the thin barite vein and the adjoining gravelly/breccial and weathered basement materials having nearly the same resistivity thereby making the thin barite layer to be an equivalent layer to the adjoining thick materials. This 
problem can be explained by the principles of equivalence and suppression and can be resolved using an integrated approach where possible. Yadav et al. (2010) have presented discussions on the influence of these problems on resistivity data interpretation. The ERT subsurface images show the barites as mineralised structures with limited vertical and lateral spread (vein structures). Correlation of the ERT results with the exposed lithologies on the abandoned mining pits and other surface exposures in the area show that the barite veins are thin compared to the thickness of the adjoining materials. Such subsurface conditions might have caused the electrical signature of the barite vein to be suppressed in both the VES curves and the ERT images outside the major vein.

The high value of the UCS of the barite ores was attributed to the frictional resistance by its associated minerals (Ene et al., 2012). Standard specifications of barites and other minerals exist for different industrial purposes and any barite deposit whose composition falls below these specifications are considered to be of low quality and hence not acceptable. For instance, the American Petroleum Institute (API) specifies that for barite to be suited for use as a weighting agent in the oil industries and its specific gravity value must not be less than 4.2. Since the specific gravity of the Okurike Barite deposit is higher than this API-specified threshold value, then the Okurike Barite ores may be suitable for use in the industry as a weighting agent, production of barium-based pharmaceuticals, paints, glass and other chemicals product.

\section{Conclusions}

This study reveal that the Okurike Barites consist of stratabound syngenetic-diagenetic deposits, stratiform deposits, veinlets with sandstones and clays as host rocks. Barite mineralisation occurs as a thin vein-filling structure within a limited area in the Okurike Community. The barite ores are occasionally mixed with gravel, breccias and weathered basement materials with resistivity values that vary between 731 and $\sim 1500 \Omega \mathrm{m}$. However, since the dominant geophysical method used in this study is the electrical resistivity method, the sandstone-limestone interface might not have been properly delineated due to lack of reasonable resistivity contrast in some locations. Thus, it may be necessary to conduct a direct investigative method such as core drilling in order to establish the economic worth of the barite deposit. Other geophysical techniques such as seismic refraction tomography and ground penetrating radar should also be performed in order to generate an independent shallow subsurface image.

The physical characteristics of the barites are 4.4 for specific gravity, $3.64 \mathrm{~g} / \mathrm{cm}^{3}$ for density, $28 \%$ for porosity, $29.4 \mathrm{kN} / \mathrm{mm}^{2}$ for UCS and $1.5 \%$ for water absorption. The barites are preferentially enriched in $\mathrm{Ba}$ $(77.28 \%)$ and $\mathrm{Fe}(19.98 \%)$. The composition of other elements was less than $1 \% . \mathrm{BaO}, \mathrm{Fe}_{2} \mathrm{O}_{3}$ and $\mathrm{MnO}$ dominate the ore composition of the samples with percentage composition of $71.28,21.40$ and $6.10 \%$ respectively. These results show that the Okurike Barites are of high industrial quality with specific gravity higher than the API-specified value of 4.2.

\section{Acknowledgment}

The researchers are grateful to the Chiefs and Youths of Okurike Community for their assistance and cooperation during field data acquisition. The authors are also grateful to the Management of the University of Calabar for providing the necessary facilities used in the study. The contributions of the Reviewers in shaping the original manuscript to its present form are gratefully acknowledged.

\section{Author's Contributions}

All authors equally contributed in this work.

\section{Ethics}

This article is original and contains unpublished material. The corresponding author confirms that all of the other authors have read and approved the manuscript and no ethical issues involved.

\section{References}

Adeleye, D.R. and E.A. Fayose, 1978. Stratigraphy of the type section of Awi Formation, Odukpani Area, SouthEastern Nigeria. Nigeria J. Mining Geol., 15: 35-37.

Akpan, A.E., T.E. Chidomerem and I.O. Akpan, 2014. Geophysical and laboratory studies of the spread and quality of the odukpani limestone deposit. Am. J. Environ. Sci., 10: 347-356. DOI: 10.3844/ajessp.2014.347.356

Akpan, A.E., E.E. Ukwang and E.O. Esu, 2011. Assessment of the potentials of some engineering materials in parts of Akamkpa, southern Nigeria. J. Mining Geol., 40: 113-119.

Akpeke, G.B., B.N. Ekwueme and B.E. Ephraim, 2006. The nature and origin of the Barite mineralisation in Akpet area, Oban Massif, Southern Nigeria. J. Geological Sci., 4: 139-373.

ASTM D-2938-79, 1980. Standard Method of Test for Compressive Strength of Rock Core Specimens. In: Annual Book of ASTM Standards, Part 19: 440-443.

Caputo, R., S. Piscitelli, A. Oliveto, E. Rizzo and V. Lapenna, 2003. High-resolution resistivity tomographies in active tectonic studies. Examples from the Tyrnavos Basin, Greece. J. Geodynam., 36: $19-35$. 
Cratchley, R. and P. Jonesg, 1965. An Interpretation of the Geology and Gravity Anomalies of the Benue Valley, Nigeria. 1st Edn., H.M. Stationery Office, London, pp: 26.

CRBDA, 1982. Inventory of natural site conditions, soil slopes, hydrology, land use and vegetation throughout the area of operation of the authority.

Daspan, R.I. and L.O. Imagbe, 2010. Preliminary investigation of the origin and quality of barytes in the Tsereta-Tungan Kudaku Area, North Western Nigeria Basement Complex. Continental J. Earth Sci., 5: 8-13.

Ekwueme, B.N., E.E. Nyong and S.W. Petters, 1995. Geological Excursion Guidebook to Oban Massif, Calabar Flank and Mamfe Embayment, Southeastern Nigeria. 1st Edm., Dechord Press, Calabar, ISBN-10: 9783235427, pp: 36.

Ene, E.G., C.O. Okogbue and C.I.P. Dim, 2012. Structural styles and economic potentials of some barite deposits in the Southern Benue Trough, Nigeria. Romanian J. Earth Sci., 86: 27-40.

Gowd, S.S., 2004. Electrical resistivity surveys to delineate groundwater potential aquifers in Peddavanka watershed, Anantapur District andhra Pradesh, India. J. Environ. Geol., 46: 118-131. DOI: 10.1007/s00254-004-1023-2

Iloje, N.P., 2001. A new Geography of Nigeria. 1st Edn., Longman Nigeria PLC, Ibadan, pp: 200.

Inman, J.R., 1975. Resistivity inversion with ridge regression. Geophysics, 40: 798-817. DOI: 10.1190/1.1440569

Bieniawski, Z.T. and M.J. Bernede, 1979. Suggested methods for determining the uniaxial compressive strength and deformability of rock materials: Part 1. Suggested method for determining deformability of rock materials in uniaxial compression. Int. J. Rock Mech. Min. Sci. Geomech. Abstr., 16: 135-140. DOI: 10.1016/0148-9062(79)91451-7

Keller, G.V. and F.C. Frischknecht, 1966. Electrical Methods in Geophysical Prospecting. 1st Edn., Oxford, Pergamon Press, pp: 517.

Loke, M.H., 2002. RES1D version 1.0 for Windows 95/98/Me/2000/NT. 1-D Resistivity, IP and SIP Inversion and forward modelling for Wenner and Schlumberger arrays.

Loke, M.H. and R.D. Barker, 1996. Rapid least-squares inversion of apparent resistivity pseudosections by a Quasi-Newton method. Geophysical Prospect. J., 44: $\quad 131-152$. DOI: $10.1111 /$ j.13652478.1996.tb00142.x
Oden, M.I., 2012. Barite veins in the Benue Trough: Field characteristics, the quality issue and some tectonic implications. Environ. Natural Resources Res., 2: 21-31. DOI: 10.5539/enrr.v2n2p21

Oladapo, M.I. and O.O. Adeoye-Oladapo, 2011. Geophysical investigation of barite deposit in Tunga, Northeastern Nigeria. Int. J. Phys. Sci., 6: 4760-4774. DOI: $10.5897 /$ IJPS11.337

Orellana, E. and A.M. Mooney, 1966. Master Curve and Tables for Vertical Electrical Sounding over Layered Structures. 1st Edn., Interciencia, pp: 159.

Petters, S.W., 1989. A regional hydrogeological study of rural water supply options for planning and implementation of phase II rural water programme in Cross River State. Unpublished Technical Report submitted to DFFRI, Cross River State, pp: 97.

Reijers, T.J.A. and S.W. Petters, 1987. Depositional environments and diagenesis of Albian carbonates on the Calabar flank, SE Nigeria. J. Petroleum Geol., 10: 283-294. DOI: 10.1111/j.17475457.1987.tb00947.x

Reyment, R.A., 1965. Aspect of the Geology of Nigeria. 1st Edn., Ibadan University Press, Ibadan, pp: 145.

Vender Velpen, B.P.A., 1988. A computer processing package for D.C. resistivity interpretation for an IBM compatibles.

Wilkinson, P.B., P.I. Meldrum, O. Kuras, J.E. Chambers and S.J. Holyoake et al., 2010. High-resolution electrical resistivity tomography monitoring of a tracer test in a confined aquifer. J. Applied Geophys., 70: 268-276. DOI: 10.1016/j.jappgeo.2009.08.001

Yadav, G.S., A.S. Dasgupta, R. Sinha, T. Lal and K.M. Srivastava et al., 2010. Shallow sub-surface stratigraphy of interfluves inferred from vertical electric soundings in western Ganga plains, India. Quaternary Int., 227: 104-115. DOI: 10.1016/j.quaint.2010.05.030

Zhou, W., B.F. Beck and A.L. Adams, 2002. Effective electrode array in mapping karst hazards in electrical resistivity tomography. Environ. Geol., 42: 922-928. DOI: 10.1007/s00254-002-0594-z 